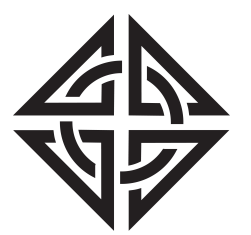

SCIENTIA
Sharif University of Technology

Scientia Iranica

Transactions E: Industrial Engineering

http://scientiairanica.sharif.edu

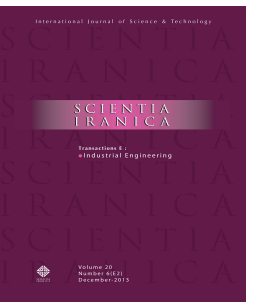

\title{
Inventory model optimization revisited: Understanding service inventories to improve performance
}

\author{
L.E. Cárdenas-Barrón ${ }^{\mathrm{a}, *}$, J. Reynoso ${ }^{\mathrm{b}}$, B. Edvardsson ${ }^{\mathrm{c}}$, \\ and K. Cabrera ${ }^{b}$ \\ a. Department of Industrial and Systems Engineering, School of Engineering and Sciences, Tecnologico de Monterrey E. Garza \\ Sada 2501 Sur, Monterrey, N.L., Mexico, C.P. 64849. \\ b. EGADE Business School, Tecnologico de Monterrey Rufino Tamayo y Eugenio Garza Lagüera, San Pedro Garza García, N.L., \\ Mexico, C.P. 66269. \\ c. Karlstad University - Service Research Center Universitetsgatan 2, 651 88, Karlstad, Sweden.
}

Received 23 January 2018; received in revised form 7 August 2018; accepted 3 November 2018

\section{KEYWORDS}

Service;

Inventory model;

Optimization;

Performance.

\begin{abstract}
Services are becoming increasingly important in the modern economy for both service and manufacturing firms; however, the inventory literature is focused mainly on physical goods and, thus, only few studies have considered services in optimization. Further to that, the traditional service management literature relies on an extremely narrow definition of inventory that excludes services because they are perishable. Thus, there is a lack of research on possible links between inventory optimization and service management. However, according to a new service inventory approach, business components such as tasks or information, as different from physical goods, can be performed and stored in anticipation of service demand as a form of service inventory, that is, inventorying by anticipation rather than delaying the service. This paper aims to contribute to this lack of research by proposing a service inventory optimization model that integrates a service orientation to optimize tasks and information to be performed in advance. In contrast with the traditional inventory models where the objective is to optimize physical items, in this approach, physical products (whenever included) constitute only mechanisms for service provision. This service inventory model contributes to the optimization of the quantity of tasks or information to be anticipated and, thus, provides customers with a number of benefits.
\end{abstract}

(C) 2020 Sharif University of Technology. All rights reserved.

\section{Introduction}

Inventory is widely researched in production and operations literature [1] and deeply relevant to the performance of any organization. More than a century

\footnotetext{
* Corresponding author. Tel.: +52 8183284235 ; Fax: +528183284153

E-mail addresses: lecarden@tec.mx (L.E.

Cárdenas-Barrón); jreynoso@itesm.mx (J. Reynoso);

Bo.Edvardsson@kau.se (B. Edvardsson);

A00795622@itesm.mx (K. Cabrera)
}

doi: $10.24200 /$ sci.2018.50333.1639 ago, Harris [2] proposed the first inventory model, Economic Order Quantity (EOQ), which became a classical reference due to its appealing simplicity, flexibility, and focus on optimization. Yet, this classical paradigm refers solely to physical products: unitary items that manufacturing companies can order in lots, store in a warehouse, and ultimately use to maximize their productivity, from groceries in retailing to spare parts in transportation to food in restaurants to medical items in hospitals. With this view, inventory management literature largely ignores the storage and optimization of non-physical components or service activities. Several inventory optimization models adopt an internal, 
goods-oriented logic with a focus on optimizing benefits for the vendor, without addressing customers' needs.

For traditional manufacturing firms, this perspective makes sense. They frequently regard services as added value or simply a sales tactic to remain competitive. However, modern manufacturing companies are increasingly adopting service provision positions, transitioning from supplying goods to providing services that actually create value for customers [3-5]. According to this logic, the reason for any company to exist is creating value for its customers and shareholders; thus, it must integrate goods and services together to satisfy customers and stay competitive. Hence, to foster profit maximization and improve service quality on a long-term basis, companies need to strategically identify and manage the optimal levels of service productivity [6].

Even as services have become more important throughout modern economies, this topic continues to be excluded from the inventory optimization literature. As a result of a systematic search performed to identify papers featuring inventory models dealing with services, no inventory models addressing service activities were identified, leading to a knowledge gap. By expanding the understanding of inventory optimization issues in service businesses though, we could address this knowledge gap and maximize several service attributes including speed, quality, customization, and price.

Specifically, it is noted that traditional service management literature asserts that services cannot be inventoried because they are perishable $[7,8]$. For example, an empty seat in a plane cannot be kept for the next flight or a hotel room not sold tonight is lost forever. This focus on the impossibility of storing a delivered service for later use reflects an extremely narrow definition of inventory, in which services are finished products instead of bundles of attributes that are produced through sets of processes [9]. Yet, business components might also be performed and stored in anticipation of Service Demand (SD) as a form of service inventory $[9,10]$. In this form of inventorying, the central goal is anticipating, not delaying, the service. Such a service inventory approach might serve to expand a traditional optimization focus to include the non-physical components of the service organization. From this perspective, the service inventory is a set of intangible components (e.g., tasks, information) that can be performed before customer demand takes place. The goal is to identify which tasks or information can be conducted in advance to render the core service and create value. This selection depends on the characteristics of each market, the costs associated with creating the service inventory, and the desired competitive position. By developing a Service Inventory Optimization Model (SIOM) based on the
EOQ model, this study aims to expand a traditional inventory and optimization focus to include services.

It is well known that traditional goods can always be stored physically in designated places such as warehouses, distribution centers, or other areas to have them ready for use. An important question thus is whether it might be possible to use a traditional EOQ inventory model to optimize services. From a rigorous perspective, the answer is no; the traditional EOQ inventory model has been developed to optimize inventories of physical goods, and this study argues that it cannot be applied to optimize a number of intangible tasks and information required during a service delivery process. Additionally, traditional inventory models work on the assumption that physical goods are standardized given their material attributes (e.g., size, weight, volume, etc.). In contrast, service processes, although following standardized protocols in many cases, experience a number of expected and unexpected changes and variations during their execution, and we argue that they require a different optimization approach from the products' perspective. Furthermore, a traditional EOQ inventory model calculates the cost of inventory as the product of the per-unit inventory cost and the inventory average, reflecting the notion that the inventory levels of physical units are constantly changing over time. However, in the service inventory model proposed here, service tasks and information that can be prepared in anticipation are always ready on a particular time horizon, with the corresponding costs. In turn, there is not necessarily an average use of tasks or information in calculating the inventory cost. This status justifies the construction of a new service inventory model; this paper proposes a service inventory model with a service orientation that seeks to optimize the tasks and information to be performed in advance, in which physical products function as mechanisms for service provision. Although different in focus and orientation, this approach still aims to reduce costs by optimizing the costs related to anticipating the execution of some portion of work that can improve customers' benefits in terms of service quality, speed, service variety (customization), or price. The challenge is to select and perform tasks or information that will be truly valuable for customers and that competitors cannot imitate, such that the business operations become unique. In this view, companies must rethink how and when they should use their resources, as well as how suppliers and customers can participate in advancing some tasks or information, to involve these partners in collaborative value co-creation roles.

In sum, service is the result of the interactions taking place between customers and suppliers through personnel, physical resources, and processes, aiming to satisfy customer needs [11]. Such processes require the execution of tasks and information. Traditionally, 
due to their intangible and perishable nature, services, arguably, cannot be "inventoried"; thus, they happen during the service delivery process. In this paper, a way to conceptualize service inventory is proposed by anticipating the execution of service tasks and information as a means to virtually "store" some part of the service to be performed, aiming to improve quality, customization, speed, and price. Based on this proposition, the service inventory model determines the optimal quantity of service tasks and information to be anticipated; therefore, they can be virtually "stored" to be ready for use before service is required by the customer. No existing service inventory model focuses on the optimization of anticipated intangible components (tasks and information) while integrating internal (provider) and external (customer) perspectives. Therefore, a multi-disciplinary approach is adopted that integrates EOQ inventory contributions with service management research to propose a new SIOM that contributes to the optimization of some part of the service (tasks or information) prior to customer demand and, thereby, provides benefits for customers including higher service quality, greater speed, enhanced service customization, or lower prices. The proposed service inventory model contributes to not only inventory research, but also service research, as this model is rooted in the notion that service components can be inventoried by incorporating the customer perspective; in addition, the model contributes to a better understanding of how anticipation and optimization might affect customer benefits.

The rest of the article is structured as follows. Section 2 begins with the proposed theoretical framework and a review of the existing EOQ inventory models. Section 3 presents a detailed derivation of the proposed service inventory model. Section 4 contextualizes the service inventory model with some service business examples. Finally, Section 5 details the conclusions and Section 6 offers some suggestions for further research.

\section{Theoretical framework}

\subsection{Existing work on EOQ inventory models}

Sellers of goods must determine the quantity of products to purchase from suppliers to satisfy customer demand and still achieve profitability. Lot sizing and optimization thus are critical issues for manufacturing companies, with direct impacts on the economic efficiency of their activities; therefore, various approaches in prior literature address these challenges (e.g., [12]. The EOQ inventory model can determine optimal inventory levels while minimizing the total cost associated with the purchase, delivery, and storage of products $[1,2,13]$. A century after its initial publication, the EOQ has extended in various ways, as researchers have added incremental conditions in an attempt to model real-world situations. Thus, the EOQ provides a foundation for a large number of papers that relax different restrictions to build new inventory models with emphasis on cost and profit, which reflect specific, actual situations.

An early extension of the EOQ sought to resolve scheduling difficulties associated with lot sizes $[2,14]$. Later research included quantity discounts [15], the production (or replenishment) rate, backorders with stockout penalties, and inflation [16,17]. A dynamic version of the lot-sizing problem also appeared [18]. The extensions of the EOQ grew exponentially, leading to EOQ with multiple setups costs [19], a present value formulation [20], a stochastic version [21], temporary one-time discounts [22], an EOQ with learning [23], EOQ models with nonlinear holding costs [24], deteriorating items [25-28], supplier credits [29], imperfect quality [30,31], recycling [32-34], EOQ for reverse logistics environments [35,36], and partial and full backordering $[37,38]$ to mention just a few.

In several good reviews of EOQ inventory modeling approaches, Pentico and Drake [37] summarized EOQ inventory models related with partial backordering, while Khan et al. [39] offered an overview of all extensions with imperfect quality, and Bouchery et al. [40] reviewed the integration of the EOQ inventory model into sustainability research. Andriolo et al. [41] explored the evolution of these extensions over a century and, also, provided a research agenda that suggests, among other things, developing integrated inventory models to include environmental aspects for sustainable supply chains and studying the social impact of inventory and purchasing decisions. Glock et al. [42] provided an excellent survey of literature reviews on EOQ models to help primary researchers position their own research, reveal the different types of EOQ inventory models, and identify new starting points for research. Janssen et al. [43] presented an upto-date review of perishable inventory models, which is a complement to the review of Bakker et al. [44]. Shekarian et al. [45] presented an ample review in the arena of fuzzy inventory management with the aim to identify and classify the main achievements obtained. Recently, Kok et al. [46] proposed a typology for the multi-echelon inventory field. This typology is applied to categorize and review the widespread research of multi-echelon inventory models under uncertain demand.

\subsection{Inventory models with service components} Despite the extensive literature on inventory models and optimization, few studies have considered service as a core factor or component. Recognizing the evident need to develop a theoretically solid and managerially relevant conceptualization of inventory models, we 
reviewed existing research to build on those pieces that have discussed service issues. Specifically, to identify papers that feature inventory models dealing with services, we searched for "service inventory model" in the Scopus database, restricting our search to paper titles so that we could find publications whose primary consideration was service in inventory models. No publications used "service inventory model" as a compound term; thus, we modified this search to identify publications including any of these three words in their titles. As a result, 72 papers, from 1981 to 2018, were found, and both their topics and the components included in their proposed models were reviewed. After excluding the articles that did not feature any service notions, 42 papers were obtained that could help us determine how the term "service" was conceptualized. According to this analysis, in existing inventory literature, service refers to the service level and plays a role as an indicator of system performance, either as a conceptual notion or a component within inventory models.

For example, five articles that linked the service level, as a conceptual notion, to other performance measures such as the accomplishment of preestablished target goals, quality, or responsiveness were found. Thiel et al. [47] showed that service-level quality was a non-monotone function of the inventory record's inaccuracy rate; Samadi et al. [48] asserted that the quality of the services offered to customers was a significant factor that directly affected demand and, therefore, must be considered for developing inventory models. With a Monte Carlo simulation model for a legal firm, Swenseth and Olson [49] built a professional service inventory chain, taking into account the need to satisfy demand, minimize costs, and maintain a good quality level, such that professional services personnel were managed as inventories. Gzara et al. [50] proposed two integrated network design and inventory control models for a service-part logistics system to fulfill warehouses' service-level requirements and, finally, Byun et al. [51] derived a probabilistic inventory model for wireless service providers.

In the remaining 37 publications, the service level as a component of the inventory model constitutes the predominant approach. In these existing models, the service level denotes the rate at which performance goals are achieved (e.g., the percentage of calls answered by a call center); therefore, it mainly functions as a constraint.

The service level constraint refers to the availability of the stock needed to deliver the expected service level at a minimum cost, which may reflect three common service-level measures: the stockout or ready rate $\alpha$, the fill rate $\beta$, or the cumulative fill rate $\gamma$ service level. According to Schneider [52] and Chen and Krass [53], the $\alpha$ service level reflects the probability that the inventory on hand does not fall below a critical level at the end of any period; the $\beta$ service level expresses the expected fraction of demand covered from inventory on hand in any period; in addition, the $\gamma$ service level expresses the expected ratio of cumulative demand that can be covered from inventory to the total cumulative demand during the lead time, plus a review period. This measure is thus equivalent to $\beta$, except that the ratio spans multiple periods rather than just one unique period.

As is shown in Table 1, most inventory models include service level as a constraint using the fill rate level. In all cases, the service level constraint is imposed while minimizing the total cost of an inventory system.

Inventory models are also traditionally focused on systems optimization to accomplish performance goals; however, more recent research increasingly expands the model restrictions to include new components, as service levels, and thus better simulate real-world situations. Over time, inventory models have become more sophisticated, especially as supply chains grow to involve more actors and operations facing more complex circumstances. All these contributions allow for cost reductions and better performance, but they also have neglected intangible components and customer needs. This knowledge gap strongly indicates the need for a wider, multidisciplinary approach to integrate service components in inventory models.

\subsection{Service research with an inventory component}

Service research initially emphasized goods versus services dichotomy. Services were defined in relation to goods and how they could be produced and marketed. The distinctive characteristics of services such as their Inseparability, Heterogeneity, Intangibility, and Perishability (IHIP) were considered unique to them and, in a traditional goods-oriented logic, value was attached to the product or service from the provider's perspective only [54]. However, IHIP characteristics might be neither exclusive nor generic to services, since they vary across different situations and conditions. Therefore, IHIP characteristics require further exploration from a customer perspective, particularly in relation to how to manage them to create memorable customer experiences [55].

The resulting paradigm change challenges the idea that inventories are limited to material goods $[10,56]$. Services might be "stored" in systems, machines, knowledge, people, and networks in line with a metaphor in which "the ATM is a store of standardized cash withdrawals. The hotel is a store of rooms" ([56], pp. 123-24). In other cases, services might be routinely inventoried before "production," purchase, or consumption, as the case of airlines or theaters, rather than solely after production. "When a university hires 
Table 1. Existing inventory models integrating service level components.

\begin{tabular}{|c|c|c|}
\hline Authors & Service component & Main contribution \\
\hline Schneider [52] & $\begin{array}{l}\text { Service level as constraint } \\
\text { (stockout level, fill rate level, } \\
\text { and cumulative fill rate level) }\end{array}$ & Evaluation of three common service-level measures \\
\hline Mehrez \& Ben-Arieh [71] & $\begin{array}{l}\text { Service level as constraint } \\
\text { (stockout level) }\end{array}$ & $\begin{array}{l}\text { Extensive multi-item inventory model with } \\
\text { probabilistic demand and service level constraints }\end{array}$ \\
\hline Lagodimos $[72]$ & $\begin{array}{l}\text { Service level as constraint } \\
\text { (stockout level, fill rate level, } \\
\text { and cumulative fill rate level) }\end{array}$ & $\begin{array}{l}\text { Multi-echelon models for evaluating the service } \\
\text { performance of two-echelon divergent } \\
\text { networks operating under periodic review } \\
\text { statistical inventory control echelon-based } \\
\text { policies and using either a push or } \\
\text { a pull rationing policy }\end{array}$ \\
\hline Ouyang \& Wu [73] & $\begin{array}{l}\text { Service level as constraint } \\
\text { (fill rate level) }\end{array}$ & $\begin{array}{l}\text { Mixture inventory model with lead time and } \\
\text { order quantity as decision variables. }\end{array}$ \\
\hline Hillier $[74]$ & $\begin{array}{l}\text { Service level as constraint } \\
\text { (stockout level) }\end{array}$ & $\begin{array}{l}\text { Multiple-period model with } \\
\text { service level constraints to } \\
\text { compare the effect of } \\
\text { commonality in single- and } \\
\text { multiple-period cases }\end{array}$ \\
\hline Ouyang \& Chuang [75] & $\begin{array}{l}\text { Service level as constraint } \\
\text { (fill rate level) }\end{array}$ & $\begin{array}{l}\text { Mixture inventory model with backorders and } \\
\text { lost sales, where the stockout cost } \\
\text { term in the objective function is } \\
\text { replaced by a service level constraint }\end{array}$ \\
\hline Ouyang \& Chuang [76] & $\begin{array}{l}\text { Service level as constraint } \\
\text { (fill rate level) }\end{array}$ & $\begin{array}{l}\text { Mixture of back-orders and lost sales periodic } \\
\text { review inventory model subject to a } \\
\text { service level constraint, where } \\
\text { both the lead time and the review } \\
\text { period are decision variables }\end{array}$ \\
\hline Chen \& Krass [53] & $\begin{array}{l}\text { Service level as constraint } \\
\text { (stockout level, fill rate level, } \\
\text { and cumulative fill rate level) }\end{array}$ & $\begin{array}{l}\text { Inventory models in which the stockout cost is } \\
\text { replaced by a minimal service level } \\
\text { constraint that requires a certain } \\
\text { level of service to be met in every period }\end{array}$ \\
\hline $\mathrm{Xu}$ et al. $[77]$ & $\begin{array}{l}\text { Service level as constraint } \\
\text { (fill rate level) }\end{array}$ & $\begin{array}{l}\text { Approximate analytical two-location inventory } \\
\text { transshipment model combining the } \\
\text { order-quantity, reorder-point }(\mathrm{Q}, \mathrm{R}) \\
\text { continuous review ordering policy with the } \\
\text { hold-back amount, which limits the } \\
\text { level of outgoing transshipments. }\end{array}$ \\
\hline
\end{tabular}


Table 1. Existing inventory models integrating service level components (continued).

\begin{tabular}{|c|c|c|}
\hline Authors & Service component & Main contribution \\
\hline Lee et al. [78] & $\begin{array}{l}\text { Service level as constraint } \\
\text { (fill rate level) }\end{array}$ & $\begin{array}{l}\text { Continuous review inventory model considering } \\
\text { the mixtures of distribution of the } \\
\text { lead time demand including a service } \\
\text { level constraint in which the lead } \\
\text { time, order quantity, and reorder point are } \\
\text { decision variables }\end{array}$ \\
\hline Chu et al. [79] & $\begin{array}{l}\text { Service level as constraint } \\
\text { (fill rate level) }\end{array}$ & $\begin{array}{l}\text { Revised algorithms for mixed inventory backorder } \\
\text { and lost sales problem in which both } \\
\text { the lead time and order quantity are } \\
\text { treated as decision variables, as } \\
\text { developed by Ouyang and } \mathrm{Wu}[73]\end{array}$ \\
\hline Lee et al. [80] & $\begin{array}{l}\text { Service level as constraint } \\
\text { (fill rate level) }\end{array}$ & $\begin{array}{l}\text { Continuous review inventory model considering } \\
\text { the mixtures of distribution of the lead time } \\
\text { demand and controllable exponential backorder } \\
\text { rate. Service level constraint is also } \\
\text { included, considering lead time and the } \\
\text { order quantity as decision variables }\end{array}$ \\
\hline Liang et al. [81] & $\begin{array}{l}\text { Service level as constraint } \\
\text { (fill rate level) }\end{array}$ & $\begin{array}{l}\text { A simplified and theoretically rigorous algorithm } \\
\text { to improve the weaknesses and shortcomings of } \\
\text { Ouyang and Chuang [76] }\end{array}$ \\
\hline Hung et al. [82] & $\begin{array}{l}\text { Service level as constraint } \\
\text { (fill rate level) }\end{array}$ & $\begin{array}{l}\text { Refining Ouyang and Chuang's [76] algorithms } \\
\text { to provide an optimal replenishment } \\
\text { solution for decision-makers }\end{array}$ \\
\hline Jha \& Shanker [83] & $\begin{array}{l}\text { Service level as constraint } \\
\text { (fill rate level) }\end{array}$ & $\begin{array}{l}\text { A model for an integrated vendor-buyer problem } \\
\text { to jointly determine the optimal order quantity, } \\
\text { lead time, and number of shipments from the } \\
\text { vendor to the buyer during a production cycle } \\
\text { while minimizing total expected costs of the } \\
\text { vendor-buyer integrated system including service } \\
\text { level constraints }\end{array}$ \\
\hline Jha \& Shanker [84] & $\begin{array}{l}\text { Service level as constraint } \\
\text { (fill rate level) }\end{array}$ & $\begin{array}{l}\text { Single-vendor, single-buyer integrated production } \\
\text { inventory problem for decaying items }\end{array}$ \\
\hline Tajbakhsh [85] & $\begin{array}{l}\text { Service level as constraint } \\
\text { (fill rate level) }\end{array}$ & $\begin{array}{l}\text { Continuous-review }(\mathrm{Q}, \mathrm{R}) \text { inventory model with a } \\
\text { fill rate service constraint, relaxing the } \\
\text { assumption that the distribution of lead } \\
\text { time demand is known }\end{array}$ \\
\hline Xu \& Sun [86] & $\begin{array}{l}\text { Service level as constraint } \\
\text { (fill rate level) }\end{array}$ & $\begin{array}{l}\text { A multi-item, multi-echelon inventory system that } \\
\text { allows lateral transshipments, direct delivery, } \\
\text { and emergency ordering following stockouts }\end{array}$ \\
\hline
\end{tabular}


Table 1. Existing inventory models integrating service level components (continued).

\begin{tabular}{|c|c|c|}
\hline Authors & Service component & Main contribution \\
\hline Jaggi \& Arneja [87] & $\begin{array}{l}\text { Service level as constraint } \\
\text { (fill rate level) }\end{array}$ & $\begin{array}{l}\text { Exploration of the benefits of just-in-time philosophy } \\
\text { relative to reduced lead times and setup costs in a } \\
\text { periodic inventory model with service level constraint, } \\
\text { when the protection interval demand is } \\
\text { normally distributed. }\end{array}$ \\
\hline Joshi \& Soni [88] & $\begin{array}{l}\text { Service level as constraint } \\
\text { (fill rate level) }\end{array}$ & $\begin{array}{l}\text { A model with service level constraint and controllable } \\
\text { lead time in a fuzzy stochastic environment in which } \\
\text { expected shortages are calculated using the credibility } \\
\text { distribution, treating lead time demand as } \\
\text { fuzzy stochastic. }\end{array}$ \\
\hline Cheng et al. [89] & $\begin{array}{l}\text { Service level as constraint } \\
\text { (stockout level) }\end{array}$ & $\begin{array}{l}\text { Proposition of two variants of a production planning } \\
\text { problem in the hybrid push-pull systems. }\end{array}$ \\
\hline $\operatorname{Lin}[90]$ & $\begin{array}{l}\text { Service level as constraint } \\
\text { (fill rate level) }\end{array}$ & $\begin{array}{l}\text { A mixed inventory policy for a controlled setup } \\
\text { cost in the stochastic continuous review model, } \\
\text { involving controllable backorder rate and variable } \\
\text { lead time in which the stockout cost is replaced } \\
\text { with a service level constraint }\end{array}$ \\
\hline Ma \& Qiu [91] & $\begin{array}{l}\text { Service level as constraint } \\
\text { (fill rate level) }\end{array}$ & $\begin{array}{l}\text { A distribution-free continuous review inventory } \\
\text { model in the presence of a service level constraint }\end{array}$ \\
\hline Shahpouri et al. [92] & $\begin{array}{l}\text { Service level as constraint } \\
\text { (fill rate level) }\end{array}$ & $\begin{array}{l}\text { An integrated vendor-buyer inventory model } \\
\text { considering the lead time and ordering cost } \\
\text { as decision variables. To avoid imprecision } \\
\text { in estimating shortage costs, the service } \\
\text { level constraint is considered }\end{array}$ \\
\hline Jha \& Shanker [93] & $\begin{array}{l}\text { Service level as constraint } \\
\text { (fill rate level) }\end{array}$ & $\begin{array}{l}\text { An integrated production-inventory model in a } \\
\text { batch production environment for supplying a } \\
\text { set of buyers, with a service level constraint } \\
\text { for each buyer }\end{array}$ \\
\hline Hidayat et al. [94] & $\begin{array}{l}\text { Service level as constraint } \\
\text { (fill rate level) }\end{array}$ & $\begin{array}{l}\text { A two-echelon supply chain inventory model for a } \\
\text { single supplier and single buyer of one product, } \\
\text { facing a stochastic demand condition with the } \\
\text { reorder point as a decision variable, solved } \\
\text { simultaneously with the buyer's order quantity, } \\
\text { length of lead time for the buyer, and number of } \\
\text { shipments using the service level constraint in } \\
\text { place of the shortage cost. }\end{array}$ \\
\hline
\end{tabular}


Table 1. Existing inventory models integrating service level components (continued).

\begin{tabular}{|c|c|c|}
\hline Authors & Service component & Main contribution \\
\hline Bieniek [95] & $\begin{array}{l}\text { Service level as constraint } \\
\text { (stockout level) }\end{array}$ & $\begin{array}{l}\text { A model considering inventory location, where the } \\
\text { decision is made to minimize the holding costs } \\
\text { and supply costs of safety stock from the central } \\
\text { warehouse to the customer. }\end{array}$ \\
\hline Jiang et al. [96] & $\begin{array}{l}\text { Service level as constraint } \\
\text { (fill rate level) }\end{array}$ & $\begin{array}{l}\text { A two-echelon inventory model with one supplier and } \\
\text { several retailers to satisfy certain service levels } \\
\text { and minimize total inventory cost }\end{array}$ \\
\hline Cheng et al. [97] & $\begin{array}{l}\text { Service level as constraint } \\
\text { (fill rate level) }\end{array}$ & $\begin{array}{l}\text { Two bi-objective inventory models to minimize inventory } \\
\text { costs while maximizing customer service using cycle } \\
\text { service level and fill rate. }\end{array}$ \\
\hline Sarkar et al. [98] & $\begin{array}{l}\text { Service level as constraint } \\
\text { (fill rate level) }\end{array}$ & $\begin{array}{l}\text { Extension of the model of Moon and Choi [99] with } \\
\text { the consideration of setup cost reductions and } \\
\text { quality improvement. Initial investments and the } \\
\text { service level constraint are used to obtain the } \\
\text { optimal result. }\end{array}$ \\
\hline Yilmaz et al. [100] & $\begin{array}{l}\text { Service level as constraint } \\
\text { (fill rate level) }\end{array}$ & $\begin{array}{l}\text { Service level equation with a different approach in } \\
\text { the forward-reserve models }\end{array}$ \\
\hline Annadurai [101] & $\begin{array}{l}\text { Service level as constraint } \\
\text { (fill rate level) }\end{array}$ & $\begin{array}{l}\text { A distribution-free continuous review model in the } \\
\text { presence of a service level constraint for } \\
\text { optimizing lead time by considering an extra } \\
\text { crashing cost and ordering cost }\end{array}$ \\
\hline Jaggi et al. [102] & $\begin{array}{l}\text { Service level as constraint } \\
\text { (fill rate level) }\end{array}$ & $\begin{array}{l}\text { Revision of Ouyang and Chuang [76] and Liang } \\
\text { et al. [81] for a wide range of the levels of } \\
\text { service when demand during the protection } \\
\text { interval }(\mathrm{T}+\mathrm{L}) \text { is normally distributed }\end{array}$ \\
\hline Kurdhi et al. [103] & $\begin{array}{l}\text { Service level as constraint } \\
\text { (fill rate level) }\end{array}$ & $\begin{array}{l}\text { An integrated production-inventory model for a } \\
\text { single-vendor, two-buyer problem with partial } \\
\text { backorder and controllable lead time under } \\
\text { independent, normally distributed demand among } \\
\text { buyers. Service level constraint corresponding } \\
\text { to each buyer is included to limit shortages. }\end{array}$ \\
\hline Kurdhi et al. [104] & $\begin{array}{l}\text { Service level as constraint } \\
\text { (fill rate level) }\end{array}$ & $\begin{array}{l}\text { Two fuzzy continuous review inventory models under } \\
\text { service level constraint in the case of partial } \\
\text { backorder and when the quantity received is } \\
\text { uncertain, where order quantity, reorder point, } \\
\text { lead time, and ordering cost are decision variables }\end{array}$ \\
\hline
\end{tabular}


Table 1. Existing inventory models integrating service level components (continued).

\begin{tabular}{|c|c|c|}
\hline Authors & Service component & Main contribution \\
\hline $\begin{array}{l}\text { Hemapriya and } \\
\text { Uthayakumar [105] }\end{array}$ & $\begin{array}{l}\text { Service level as constraint } \\
\text { (fill rate level) }\end{array}$ & $\begin{array}{l}\text { Addressing the feasibility of decreasing the ordering } \\
\text { cost and the lost sales due to stockout in a continuous } \\
\text { review inventory model with shortages considering the } \\
\text { situation when the quantity received is uncertain. This } \\
\text { inventory model considers service level constraint. Here, } \\
\text { the lead time crashing cost is a function of negative } \\
\text { exponential lead time. }\end{array}$ \\
\hline Jauhari and Saga [106] & $\begin{array}{l}\text { Service level as constraint } \\
\text { (fill rate level) }\end{array}$ & $\begin{array}{l}\text { A joint economic lot-sizing problem under stochastic } \\
\text { demand for a vendor-buyer system is proposed. Here, } \\
\text { the demand and the buyer's ordering cost are considered } \\
\text { to be fuzzy. The vendor's manufacturing process is } \\
\text { imperfect and the buyer's screening process is imperfect } \\
\text { too. Additionally, the vendor has the opportunity to make } \\
\text { an investment to reduce the setup cost. }\end{array}$ \\
\hline
\end{tabular}

a new professor, tapes a lecture, or assigns resources for a course in a future semester, in effect, it is inventorying part of an educational service, and when students internalize the values of university education, they have inventoried the knowledge and skill base for lifelong learning. In short, they have created human capital that they can draw on for their benefit over many years or decades" ([54], p. 331).

Accordingly, service inventory alters the way service is conceptualized and operationalized. Following the definition offered by Vargo and Lusch ([54], p. 334), services are the "application of specialized competences (knowledge and skills) through deeds, processes, and performances for the benefit of another entity or the entity itself." Therefore, they might be considered sets of interactions that take place before, during, and after service delivery, through which service providers and customers co-create value. The interactions involve task performance, information, and other resource exchanges and affect how customers perceive the services as benefits [57].

Due to the dynamic nature of services, many researchers have attempted to find new ways to manage service capacity, increase productivity, and enhance service quality while still maximizing profits. Diverse tools and techniques have been developed to address the main issues of service operations management [58]. For example, queue and bottleneck management tools function to manage demand, especially in settings where capacity is a constraint, based on the premise that queues are inevitable. Because perceived waiting time tends to be greater than actual waiting time, these techniques attempt to reduce perceived waiting time at defined levels of resource utilization [59]. Thus, they emphasized the relevance of identifying key tasks that represent bottlenecks. Even when queuing and bottleneck management do not address service inventory, the identification of key tasks can highlight areas where a service component can be inventoried.

Operations planning and scheduling techniques focus on finding a balance between demand and supply plans at all levels by forecasting demand and organizing operations to match it, integrating overbooking, or stabilizing revenues to counteract customer noshows [60]. By planning operations, the firm can maximize its resource utilization and minimize its costs. Optimization is a key component, though even if some tasks or complete services could be scheduled and performed in advance, no formal model details a process for inventorying tasks to increase customers' benefits.

Another common concept in service operations management centers on service capacity and demand using Service Level Agreements (SLA) to lay out the terms, conditions, and penalties for the delivery of services between a service provider and customers. An SLA specifies the services to be delivered in a business relationship and exclusions; it describes how the service provider's performance will be measured and provides a legal structure for relationship management including contract monitoring and dispute resolution. It also specifies the remuneration for core services and expenses incurred and offers a means to calculate the cost of additional (non-core) services [61,62]. A key advantage of SLA is that it prepares both provider and customer to co-create the service, with the potential for identifying tasks and information that need to be performed or obtained before the service can be 
delivered. However, their application has been limited to specific industries.

In contrast, the yield management approach, originally used by airlines, is widely adopted to help service firms in various industries manage their service capacity more profitably. This technique applies information systems and price strategies to maximize company revenues and profit. Prices are set according to predicted demand levels, allowing price-sensitive customers who are willing to purchase at off-peak times to obtain favorable prices, while price-insensitive customers who want to purchase at peak times also can do so $[63,64]$. Yield management uses reservation systems to distribute demand [65]. These practices represent a type of service inventory, from the provider's perspective, because they help minimize costs and maximize profits. However, yield management does not address customers' needs. With focus on profits, it is frequently perceived by customers as unfair, especially in industries where the practices are not common [6668]; therefore, it affects perceived service quality.

The increasing use of information systems also has made data analysis more relevant across all the previously mentioned techniques. Data mining, as an interdisciplinary approach, supports the discovery of patterns in large datasets by leveraging artificial intelligence, machine learning, statistics, and database systems. The main goal is to extract information and turn it into valuable knowledge about business activities (markets, employees, customer habits and preferences, patterns, and trends); therefore, it represents a very useful tool to manage capacity and demand [69].

The contributions discussed in this section have been made mainly by service academics and practitioners, looking for innovative ways to maximize service efficiency, quality, and profits. However, in this goodsdominant logic, strategies focused on internal criteria and customers play passive roles, mainly as recipients and not as participants, such that their needs are rarely even considered. Optimization has a role, but not necessarily focused on customer benefits. Despite some of these approaches that are based on the notion of planning or forecasting service operations, we found no evidence that they conceptualized anticipation as a service component to be optimized. Thus, we argue for the need of developing a service inventory model that addresses service from a wider perspective as a collection of processes including intangible components (tasks and information) that can be anticipated and optimized to maximize both organizational and customer benefits.

\subsection{Service inventories}

As discussed previously, the dominant view in inventory research implies that only physical products can be inventoried. The lack of research on non-physical components in inventory models may be due to the difficulty associated with modeling inventory service tasks or information. Service inventory based on tasks or information differs completely from product inventory; therefore, the considerations in managing service inventory must be distinct from those in managing physical products. Many service textbooks promote the notion that intangibles such as services cannot be stored [70]. However, the previously noted change in the way that service characteristics (Inseparability, Heterogeneity, Intangibility, and Perishability IHIP) have been conceptualized emphasizes the need for an extended service inventory definition. From this perspective, some service operations management concepts might be considered precedents of service inventories; however, no integral approach exists that translates these efforts into customer benefits.

According to Chopra and Lariviere [9], a service inventory includes the processes performed before the clients' arrival, to request a service. Thus, a kind of buffer of service tasks or information arises to help deal with variability in demand and establish a quicker response time to clients' requests. In other words, service tasks or information might be completed by the anticipation of demands so that organizations can create customer value through better response times, quality, customization, and prices. In this process, customers engage in different levels of participation either as part of the anticipation, by providing information or performing a task, or as a beneficiary of the service anticipation $[9,10]$. These arguments suggest the potential for a new SIOM, as detailed next.

\section{Towards developing a Service Inventory Optimization Model (SIOM)}

The proposed service inventory model is based on the analysis of the traditional EOQ inventory model components and key concepts from service research. In building this model, we consider anticipation, of tasks or information, as a cost; this anticipation cost is the main unit of analysis and the variable to be optimized. Thus, the selection of key tasks and information to be anticipated represents a significant decision, determined by the provider, depending on its industry, performance goals, and expected impact in terms of customer benefits (quality, speed, customization, and price). In line with the traditional EOQ model, different cost categories are also considered to build this service inventory model, namely Service Inventory Organization Costs (SIOC), Service Inventory Execution Costs (SIEO), and Service Inventory Costs (SIC). However, as different from inventorying manufactured goods, these sets of costs are developed to reflect the need for organizing, executing, and preparing the use 
of those anticipated tasks and information as a way of service inventory.

In contrast with the traditional EOQ model where the inventory level is changing over time requiring an average inventory level to be calculated, in the Service Inventory Optimization Model (SIOM), there is no need for "storing" tasks and information limited to physical space; they could be virtually "stored" almost infinitely. Therefore, there is no need to establish a parameter to determine the moment at which service tasks and information should be anticipated again in the service process. This always allows keeping the optimal level of tasks and information virtually "stored", guaranteeing the appropriate service provision to customers and improving quality, customization, speed, or price.

In this section, the arguments for identifying each of the cost components of the SIOM are detailed next; in general, service dynamics across pre- and production stages is captured and the operationalization of service inventories is enabled [9].

\subsection{Service Inventory Organization Cost (SIOC)}

The anticipation of tasks or information to ensure that the service is ready to be provided when the client needs it is crucial in competitive markets, especially because perceived waiting time has such a notable influence. Long waits might even cause customers to decline to buy the service, leading to lost sales. Identifying which relevant tasks and information to anticipate and getting organized to anticipate them can create costs, or service inventory organization costs (SIOC), which can be expressed in dollars per anticipation. That is, SIOC represents the cost of getting organized to perform each anticipation of tasks or information to be ready to serve customers such as gathering resources required to ensure the tasks or information are ready before they are required as part of the service.

\subsection{Service Inventory Execution Cost (SIEC)}

The cost of actually performing tasks or information in advance can be expressed in dollars per anticipated task or information. It constitutes the Service Inventory Execution Cost (SIEC).

\subsection{Service Inventory Cost (SIC)}

When a service is delivered, those service tasks and information anticipated before are used (in that service) and, thus, they are anticipated again to keep the optimal number (of tasks and information). Thus, following the anticipation, tasks or information are "waiting" for some time before being used; then, once used, they are immediately "replaced" by new ones so that they can always be ready for the next customer. In this case, there is a related Service Inventory Cost ( $S I C$ ), accounted for in dollars per task or information and per time unit. That is, SIC is the cost incurred for having the anticipated task or information ready and waiting to be used as part of the service. As explained earlier, virtually "storing" these anticipated tasks or information always allows keeping their optimal level needed to be ready for use without waiting for a "reorder" level, as there is no need to establish a parameter to determine the moment when service tasks and information should be anticipated again in the service process, guaranteeing the appropriate service provision for customers and improving quality, customization, speed, or price.

This conceptualization represents a key difference from the traditional EOQ model, where the inventory level is changing over time requiring an average inventory to be calculated due to physical space limitations related to tangible goods, thus requiring the definition of a reorder parameter.

\subsection{Service Demand (SD)}

Service Demand (SD) reflects the total number of services performed to satisfy customers' requirements. Every time a customer requests a service, some tasks must be performed, and information must be used to cover the SD. Based on the goal to be achieved in terms of customer benefits, SD might include a predetermined number of anticipated tasks or information. Thus, SD is expressed as the total tasks or information per time unit.

\subsection{Quantity of Service Inventory (QSI)}

The decision variable in the service inventory model is the quantity of service inventory (QSI) that is equal to the quantity of tasks or information required to be conducted in advance to be ready when the service is requested by the customer so that the service provider can co-create value with customers.

\subsection{Total Service Inventory Cost (TSIC)}

The Total Service Inventory Cost (TSIC) comprises three category costs. First, the total SIOC of all anticipations during a planning horizon (e.g., a year) is the product of the cost of getting organized to perform one anticipation (SIOC) and the number of anticipations required on that time horizon. The number of anticipations is equal to the total SD divided by the QSI $\left(\frac{\mathrm{SD}}{\mathrm{QSI}}\right)$. Therefore, total SIOC can be expressed as follows:

$$
\frac{[S I O C][S D]}{Q S I} .
$$

Second, this paper includes the TSIC of tasks or information performed in anticipation, which is the product of the SIC and the QSI. Each anticipation is conducted and "stored," waiting to be used as part of the service and, then, is immediately replaced; 
therefore, this cost is always recurring. The TSIC of tasks or information is therefore determined as follows:

$[S I C][Q S I]$.

Third, the total SIEC of all anticipations is calculated by multiplying the SIEC associated with each anticipated task or information to satisfy customers' SDs. Formally,

$[S I E C][S D]$.

Combining these three cost categories, we can derive the TSIC function to be optimized (TSIC) as follows:

$$
\begin{aligned}
T S I C(Q S I)= & \frac{[S I O C][S D]}{Q S I}+[S I C][Q S I] \\
& +[S I E C][S D] .
\end{aligned}
$$

\subsection{Service Inventory Optimization Model (SIOM)}

The preceding function contains a unique decision variable, namely the QSI. Simplifying the SIOM with differential calculus, we obtain:

$$
Q S I=\sqrt{\frac{[S I O C][S D]}{S I C}} .
$$

Therefore, the SIOM indicates that the optimal quantity of service tasks or information to be performed in anticipation depends on the square root of the product of the cost of anticipating tasks or information and the tasks or information required to satisfy SD, divided by the SIC.

\section{Contextualization of the SIOM}

To highlight the relevance of the proposed new SIOM, contextualization is provided using general examples of different service tasks: preparing content for streaming, enabling mobile banking transactions, preparing practices and tools to provide business consultancy, and customizing high-end hotel room facilities according to customer needs, preferences, and habits. Services are becoming increasingly reliant on information and, due to technological advances, they include tasks that can be performed in advance to improve quality, reduce price, increase customization, and speed up service provision. Different inventory costs and model components for each of the examples are shown in Table 2 in detail. Each contextualization case begins by detailing the internal criteria used to select the tasks or information to be anticipated. Then, each model component is contextualized for a range of selected cases. The external criteria for optimization (quality, customization, speed, and price) then lead to the brief descriptions of the functions to be optimized. Finally, in Table 2, how customers participate in advancing tasks or information, as well as in the service itself, is explained.

\subsection{Anticipating part of the service}

The selection of tasks and information to be anticipated depends on the characteristics of the industry, the costs associated with anticipation, expected business performance, and the expected customer benefits (quality, price, customization, and speed). This process is relevant, in that the anticipation of selected tasks or information represents the service components to be optimized.

For example, for content streaming, the selected anticipation is a specific content (movie, song) that is ready to be delivered, 24/7. In this industry, having songs, movies, and other digital contents ready prior to customer demand is an absolute necessity, because customers expect a quick response and the flexibility to customize their content selection according to their preferences. For mobile banking, anticipation entails banking operations that are ready to be performed through mobile devices. Similar to content streaming, this anticipation reflects industry practices and customer expectations of availability, security, and customization.

In a business consultancy setting, the tools and practices must be ready to be used before the customer requires them, which offers a representative example of how work can be performed in advance and stored, even when customers have completely different profiles and needs. Finally, in the high-end hotel example, the costs are associated with creating customized rooms that match specific customer preferences, needs, and habits, even before customers' arrivals. All these practices are required, because they largely determine customer satisfaction, offering a representative example of customer participation relevance in service anticipation. In all of these cases, information technology plays a key role as an enabler of service anticipation.

\subsection{Service Inventory Organization Cost (SIOC)}

The SIOC, as defined previously, is the cost of having all the resources required to perform each anticipation of task or information and, thus, advance the service to be delivered to customers. In content streaming services, this cost may entail paying for the rights to the movies or songs to be streamed, including careful selections of the premiere and classical movies, songs, or videos. The cost of these rights likely varies according to factors such as novelty and demand. The cost of being prepared for customers' content selections also involves developing robust information technology infrastructure (e.g., servers, software, and information systems) that can store and manage vast amounts of digital content and enable customers to 
Table 2. Service inventory model: components, criteria, contexts, and functions.

\begin{tabular}{|c|c|c|c|c|c|c|c|c|}
\hline $\begin{array}{l}\text { Model components / } \\
\text { case (optimization } \\
\text { internal criterion) }\end{array}$ & SIOC & SIEC & $\mathrm{SIC}$ & SD & QSI & $\begin{array}{l}\text { Optimization } \\
\text { of external } \\
\text { criterion } \\
\text { (customer) }\end{array}$ & $\begin{array}{c}\text { Function } \\
\text { optimized } \\
\text { with model } \\
\text { (internal + } \\
\text { external } \\
\text { criteria) } \\
\end{array}$ & $\begin{array}{c}\text { Customer } \\
\text { participation }\end{array}$ \\
\hline $\begin{array}{l}\text { Content streaming } \\
\text { (adding/eliminating, } \\
\text { accessing, streaming) } \\
\text { Process to deliver } \\
\text { specific content to } \\
\text { watch or hear } \\
\text { through streaming, } \\
24 / 7 \text { (e.g., Netflix, } \\
\text { Spotify) }\end{array}$ & $\begin{array}{l}\text { Cost of paying for } \\
\text { movie/series/song } \\
\text { rights to stream } \\
\text { content } \\
\text { Cost of developing } \\
\text { a system to select } \\
\text { and customize } \\
\text { preferences } \\
\text { Cost of developing } \\
\text { an ICT } \\
\text { infrastructure to } \\
\text { store and deliver } \\
\text { high-quality digital } \\
\text { content } 24 / 7\end{array}$ & $\begin{array}{l}\text { Cost of } \\
\text { uploading } \\
\text { content for } \\
\text { streaming } \\
\text { Cost of } \\
\text { categorizing } \\
\text { uploaded } \\
\text { content }\end{array}$ & $\begin{array}{l}\text { Cost of } \\
\text { maintaining } \\
\text { content to be } \\
\text { available } \\
\text { online }\end{array}$ & $\begin{array}{l}\text { Type and } \\
\text { amount of } \\
\text { content } \\
\text { available at } \\
\text { any time for } \\
\text { customer } \\
\text { access }\end{array}$ & $\begin{array}{l}\text { Optimal } \\
\text { amount of } \\
\text { content to } \\
\text { buy and keep } \\
\text { available }\end{array}$ & $\begin{array}{l}\text { Lower price } \\
\text { Greater } \\
\text { customization }\end{array}$ & $\begin{array}{l}\text { Anticipating } \\
\text { content } \\
\text { availability to } \\
\text { allow } \\
\text { customers to } \\
\text { select it freely }\end{array}$ & $\begin{array}{l}\text { Customer } \\
\text { provides } \\
\text { information } \\
\text { about } \\
\text { preferences } \\
\text { and habits. } \\
\text { Customer } \\
\text { selects content, } \\
\text { place, time, } \\
\text { and frequency } \\
\text { of use, } \\
\text { according to } \\
\text { suggestions. }\end{array}$ \\
\hline $\begin{array}{l}\text { Mobile banking } \\
\text { (accessing, } \\
\text { validating, operating, } \\
\text { and securing) } \\
\text { Process to deliver } \\
\text { banking operations } \\
\text { (consultations, } \\
\text { transfers, and } \\
\text { payments) through } \\
\text { mobile devices } 24 / 7\end{array}$ & $\begin{array}{l}\text { Cost of developing } \\
\text { a mobile } \\
\text { operations } \\
\text { portfolio } \\
\text { Cost of developing } \\
\text { ICT infrastructure } \\
\text { to provide safe, } \\
\text { fast, reliable } \\
\text { mobile banking } \\
\text { operations } 24 / 7 \text {, } \\
\text { including security } \\
\text { elements } \\
\text { (firewalls, tokens, } \\
\text { and cards) }\end{array}$ & $\begin{array}{l}\text { Cost of } \\
\text { making } \\
\text { banking } \\
\text { information } \\
\text { available } \\
\text { through } \\
\text { mobile } \\
\text { devices }\end{array}$ & $\begin{array}{l}\text { Cost of } \\
\text { maintaining } \\
\text { banking } \\
\text { information } \\
\text { available } \\
\text { online }\end{array}$ & $\begin{array}{l}\text { Amount of } \\
\text { information } \\
\text { available at } \\
\text { any time to } \\
\text { perform } \\
\text { customers' } \\
\text { mobile } \\
\text { transactions }\end{array}$ & $\begin{array}{l}\text { Optimal } \\
\text { amount of } \\
\text { information } \\
\text { available at } \\
\text { any time to } \\
\text { perform } \\
\text { mobile } \\
\text { transactions }\end{array}$ & Faster speed & $\begin{array}{l}\text { Anticipating } \\
\text { information } \\
\text { availability to } \\
\text { allow } \\
\text { customers to } \\
\text { transact with } \\
\text { mobile } \\
\text { devices }\end{array}$ & $\begin{array}{l}\text { Customer } \\
\text { downloads and } \\
\text { configures } \\
\text { mobile } \\
\text { banking apps } \\
\text { Customer } \\
\text { decides to } \\
\text { access and } \\
\text { exchange } \\
\text { information to } \\
\text { perform } \\
\text { transactions at } \\
\text { chosen place, } \\
\text { time, and } \\
\text { frequency }\end{array}$ \\
\hline
\end{tabular}

Notes: ICT $=$ Information and Communication Technology.

create digital accounts and customize their preferences. These aspects must be ready in anticipation of the tasks and information associated with streaming services. Similarly, for mobile banking, the cost of preparation for customers' selection of operations includes the development of robust information technology infrastructure; however, it features the costs of adequate security policies for banking transactions.

In business consultancy services, the cost of organizing the service inventory may involve the identification and selection of relevant tools and practices such as simulators, surveys, or business analytics tools that might facilitate the consultancy process, which have costs to acquire. In this case, an important anticipation cost relates to the selection and hiring of specialized staff, who can make an adequate balance between business customer needs and selected tools and practices. The creation of a mechanism to enable data transfers and sharing is another important cost for these services.

Finally, for high-end hotel services, preparation for customizing room facilities involves the cost of developing a set of personalization options and policies for customers, reflecting the elements most valued by customers and, also, a careful evaluation of the limits of what a hotel can offer without affecting other 
Table 2. Service inventory model: components, criteria, contexts, and functions (continued).

\begin{tabular}{|c|c|c|c|c|c|c|c|c|}
\hline $\begin{array}{l}\text { Model components / } \\
\text { case (optimization } \\
\text { internal criterion) }\end{array}$ & SIOC & SIEC & SIC & SD & QSI & $\begin{array}{c}\text { Optimization } \\
\text { of external } \\
\text { criterion } \\
\text { (customer) }\end{array}$ & $\begin{array}{c}\text { Function } \\
\text { optimized } \\
\text { with model } \\
\text { (internal + } \\
\text { external } \\
\text { criteria) } \\
\end{array}$ & $\begin{array}{c}\text { Customer } \\
\text { participation }\end{array}$ \\
\hline $\begin{array}{l}\text { Business } \\
\text { consultancy } \\
\text { (diagnosing, } \\
\text { advising, and } \\
\text { assessing) } \\
\text { Process of preparing } \\
\text { tools and practices to } \\
\text { provide business } \\
\text { consultancy services } \\
\text { to corporate clients }\end{array}$ & $\begin{array}{l}\text { To identify and } \\
\text { select standard } \\
\text { tools and practices } \\
\text { for business } \\
\text { consultancy } \\
\text { Cost of creating a } \\
\text { business } \\
\text { information } \\
\text { database (markets } \\
\text { share, trends, etc.) } \\
\text { Cost of creating } \\
\text { data sharing } \\
\text { infrastructure } \\
\text { Cost of getting } \\
\text { specialized staff }\end{array}$ & $\begin{array}{l}\text { Cost of } \\
\text { selection, } \\
\text { purchase, and } \\
\text { storage of } \\
\text { business } \\
\text { information } \\
\text { Cost of } \\
\text { developing a } \\
\text { catalogue of } \\
\text { standard } \\
\text { tools and } \\
\text { practices for } \\
\text { diagnosing, } \\
\text { advising, and } \\
\text { assessing } \\
\text { companies } \\
\text { Cost of } \\
\text { training } \\
\text { consultants to } \\
\text { use } \\
\text { standardized } \\
\text { tools and } \\
\text { practices }\end{array}$ & $\begin{array}{l}\text { Cost of } \\
\text { specialized } \\
\text { staff } \\
\text { Cost of } \\
\text { maintaining } \\
\text { business } \\
\text { information } \\
\text { database } \\
\text { Cost of } \\
\text { maintaining } \\
\text { a sharing } \\
\text { information } \\
\text { platform }\end{array}$ & $\begin{array}{l}\text { Type and } \\
\text { amount of } \\
\text { tools and } \\
\text { practices } \\
\text { required to } \\
\text { satisfy } \\
\text { business } \\
\text { customers' } \\
\text { demands }\end{array}$ & $\begin{array}{l}\text { Optimal } \\
\text { number of } \\
\text { tools and } \\
\text { practices } \\
\text { available to } \\
\text { conduct } \\
\text { consultancy }\end{array}$ & $\begin{array}{l}\text { Higher quality } \\
\text { Faster speed }\end{array}$ & $\begin{array}{l}\text { Anticipating } \\
\text { staff and } \\
\text { resource } \\
\text { (information, } \\
\text { practices, and } \\
\text { tools) } \\
\text { availability to } \\
\text { provide } \\
\text { business } \\
\text { consultancy } \\
\text { services }\end{array}$ & $\begin{array}{l}\text { Business } \\
\text { customer does } \\
\text { not participate } \\
\text { in anticipation } \\
\text { Business } \\
\text { customer } \\
\text { defines goals } \\
\text { to be achieved } \\
\text { during the } \\
\text { consultancy } \\
\text { process. }\end{array}$ \\
\hline $\begin{array}{l}\text { High-end hotels } \\
\text { (booking, registering, } \\
\text { hosting) } \\
\text { Process of } \\
\text { customizing rooms } \\
\text { according to } \\
\text { customer } \\
\text { preferences, special } \\
\text { needs, and habits } \\
\text { (e.g., Ritz-Carlton, } \\
\text { Marriot) }\end{array}$ & $\begin{array}{l}\text { Cost of developing } \\
\text { ICT infrastructure } \\
\text { to support online } \\
\text { information } \\
\text { exchange, storage, } \\
\text { and transactions } \\
\text { Cost of developing } \\
\text { a flexible } \\
\text { operation policy } \\
\text { that allows for } \\
\text { special requests } \\
\text { and empowers } \\
\text { employees }\end{array}$ & $\begin{array}{l}\text { Cost of } \\
\text { preparing } \\
\text { hotel rooms } \\
\text { according to } \\
\text { customer } \\
\text { preferences, } \\
\text { special } \\
\text { needs, and } \\
\text { habits }\end{array}$ & $\begin{array}{l}\text { Cost of } \\
\text { maintaining } \\
\text { customized } \\
\text { rooms ready } \\
\text { but not being } \\
\text { used }\end{array}$ & $\begin{array}{l}\text { Number of } \\
\text { customized } \\
\text { rooms ready } \\
\text { to be used }\end{array}$ & $\begin{array}{l}\text { Optimal } \\
\text { number of } \\
\text { customized } \\
\text { rooms ready } \\
\text { to be used }\end{array}$ & $\begin{array}{l}\text { Higher } \\
\text { customization } \\
\text { Higher quality }\end{array}$ & $\begin{array}{l}\text { Anticipating } \\
\text { room } \\
\text { availability } \\
\text { with specific } \\
\text { requirements }\end{array}$ & $\begin{array}{l}\text { Customer } \\
\text { provides data } \\
\text { about the stay } \\
\text { (dates, number } \\
\text { of guests), } \\
\text { personal room } \\
\text { preferences, } \\
\text { special needs, } \\
\text { and habits. }\end{array}$ \\
\hline
\end{tabular}

Note: $\mathrm{ICT}=$ Information and Communication Technology.

customers. It also might entail costs to acquire specific products and items (e.g., pillows, cradles, wheelchairs, and sheets). An information system is also required to support the registration and track customers' requests and preferences.

\subsection{Service Inventory Execution Cost (SIEC)}

The SIEC is the actual cost of performing the selected service anticipation. In the case of content streaming services, it may include tasks related to categorizing and uploading digital content. Even if this process 
can be automatized, it still involves some cost, which is likely the key to making customer selection more efficient. Even if mobile banking transactions can be automated, the cost of executing the defined policies and creating an operations portfolio for each customer similarly must be considered. For business consultancy services, the cost relates to the development of standardized processes to apply previously selected tools and practices to different business scenarios, including costs to train consultants in the use of standard tools and processes. Finally, high-end hotel services incur costs to adapt room facilities to special needs and customer requests, such as adding pillows, adapting the temperature, changing the sheets, or installing a cradle before a customer's arrival. It may also involve the cost of employees who are required to make these adaptations.

\subsection{Service Inventory Cost (SIC)}

Once the task or information has been anticipated, the "waiting" period begins before delivering the service. For digital content streaming and mobile banking services, it likely includes the cost of maintaining content or information online. Technology costs have steadily decreased; however, this cost might still entail the potential risk that customers do not select some contents for which the streaming service has paid or do not need extreme security policies that the bank has established. In the business consultancy setting, the cost instead refers to maintaining business tools and practices (e.g., licenses, memberships, and access) and keeping highly specialized staff "on call" to offer diagnosis and advice to customers. For high-end hotel services, these costs entail customizing room facilities according to the needs and preferences of specific customers, ready to be used. The cost of not having that room available for other customers is also featured in the SIC.

\subsection{Service Demand (SD)}

In this context, SD is the amount of tasks or information required to satisfy customer requests. Considering streaming content services, SD is not only the quantity but also the type of content that must be available for customers to select among, which in turn requires a deep analysis of customer demand patterns and external information such as new contents and formats that are likely to be released in the future. In mobile banking, it represents the mobile operations and data required to fulfill customers' requests. For the business consultancy, SD represents the number of consultants, tools, and practices needed (tools configured and employees trained) to provide service for customers. For example, if a business customer requires advice on talent management, the consulting company needs to have a human resources specialist available. Finally,
$\mathrm{SD}$ relates to the number of rooms that needs to be available for customers' use in the hotel example.

\subsection{Customer participation and impact of anticipation}

Anticipation should have effects on quality, speed, customization, and price; in the contextualization presented here, customers can function as either participants or beneficiaries. In the content streaming setting, customers participate by providing information about their preferences and habits and, as a result, they benefit from paying lower prices for contents due to economies of scale and from receiving greater customization related to when, where, and how to access the selected contents. In mobile banking, customer participation is mainly a beneficiary and able to access and exchange information to perform quick mobile transactions anytime and anywhere. Customers of the business consultancy service do not participate in anticipation; however, as beneficiaries, they receive higher service quality and speed, because the consultants have been previously trained and prepared with the most relevant tools and practices to respond to these customers' demands. When the high-end hotels prepare room facilities according to customers' needs and preferences, they provide the customers with higher quality and customization, contributing to the creation of memorable experiences, especially if those customers have already provided information about their preferences in previous visits so that the hotel can anticipate some tasks without any explicit request from customers.

\section{Limitations and further research}

With its theoretical nature, this research offers the first step toward a service inventory model that can optimize specific tasks or information to be executed in advance to enable the provision of highly valuable services for customers. Further research can continue these efforts, and we suggest several avenues here. First, it would be interesting to empirically study whether any significant differences arise in the actual performance of companies that apply traditional inventory models versus those that shift and start using the proposed SIOM.

Second, further research could measure the impacts of the services SIOM for customers, as well as how they influence the value co-creation process.

Third, it would be interesting to develop SIOMs for different settings, with varying constraints in terms of time, service quality, and human and technical resources.

Fourth, research should apply the model in different contexts and conduct empirical studies in various areas (e.g., hospitality, healthcare, and transporta- 
tion). These empirical results can form a basis for the refinement of the model.

Fifth, the proposed inventory model is developed based on the total cost function minimization. Minimizing these costs does not always produce higher profits though; therefore, further research might explore the optimization of service inventory models by considering the maximization of the profit function.

Sixth, in addressing the optimization of service operations, organizations are considered as isolated units here. However, companies are part of their surrounding business context, in which they interact with other entities. Therefore, an integrated approach might support the development of the service inventory model for an integrated supply chain, with several members in each stage of the chain.

Seventh, as a natural next step, it is suggested that the service-based inventory model be integrated with a traditional, goods-based inventory model. Most firms rely on both goods and services; thus, an integrated inventory optimization model is greatly required and can even transcend the goods versus services divide to focus instead on value and value creation for different stakeholders. In this case, researchers might include not only firms and their customers but also corporate social responsibility questions, which are becoming increasingly important for all businesses.

Eighth, research should zoom in on specific components in the model such as the SIC and quality of service inventory.

Ninth, another interesting topic for future research is making specific optimization efforts for different stakeholders such as customers, employees, owners, or shareholders, as well as service inventory optimization over different time horizons and across disparate demand situations.

Finally, future research might focus on the development of service design/redesign tools to integrate the notion of service inventory optimization into different stages of the whole customer experience journey.

Overall, we acknowledge that this manuscript aims to break new ground in the inventory theory. We intend to expand current knowledge so far limited to inventorying physical goods by setting a new framework for services. This is only the first step towards many other future contributions. It is expected that the proposed conceptual model be refined, enriched, and empirically tested for fueling additional publications.

\section{Conclusions}

This study developed a Service Inventory Optimization Model (SIOM) based on the Economic Order Quantity (EOQ) model with a focus on optimizing anticipated intangible components (tasks and information) while integrating internal (provider) and external (customer) perspectives. Therefore, this paper presented a multidisciplinary approach that integrated EOQ inventory contributions and service management research to propose a new service inventory model to optimize some part of the service (tasks or information) that can be anticipated prior to customer demand. The examples we offer on the contextualization of the model also reveal how the proposed service inventory model might contribute to the optimization of service performance, with impacts on the customer's benefits (i.e., service quality, speed, customization, and price). The application of the proposed model to identify those parts of the service to be anticipated and optimized provides companies with good insights to develop and deploy the optimal level of resources to respond to customers' demands, including technology, highly-specialized employees or redesigned processes enabling customer participation, to name a few. A key, distinctive characteristic of the proposed service inventory model is its focus on optimization as a process to provide benefits for both the firm and the customer based on a paradigm that goes beyond the traditional goods/services divide.

Finally, this service inventory optimization model can help practitioners and managers who seek to improve their business operations by reducing costs, increasing profits, and enhancing service levels. With this proposed service inventory optimization model, decision-makers can increase the customization of their organization offers and provide additional services, having an impact on customer satisfaction. Service inventory optimization might also be considered as a source of differentiation for companies as they cannot be easily imitated. In addition, by applying this model, firms can provide reliable services more rapidly, thereby enhancing the productivity of their skilled workers and the value of their services.

\section{References}

1. Choi, T.M., Handbook of EOQ Inventory Problems, International Series in Operations Research and Management Science, Springer Science + Business, New York, USA (2014).

2. Harris, F.W. "How many parts to make at once", Factory, The Magazine of Management, 10(2), pp. 135-136 (1913).

3. Gebauer, H., Ren, G.J., Valtakoski, A., and Reynoso, J. "Service-driven manufacturing: provision, evolution and financial impact of services in industrial firms", Journal of Service Management, 23(1), pp. 120-136 (2012).

4. Mathieu, V. "Service strategies within the manufacturing sector: benefits, costs and partnership", International Journal of Service Industry Management, 12(5), pp. 451-475 (2001). 
5. Young, L., From Products to Services: Insights and Experience from Companies which Have Embraced the Service Economy, John Wiley \& Sons (2008).

6. Rust, R.T. and Huang, H.M. "Optimizing service productivity", Journal of Marketing, 76(2), pp. 47-66 (2012)

7. Fisk, R., Grove, S., and John, J., Eds., Services Marketing Self-Portraits: Introspections, Reflections, and Glimpses from the Experts, Chicago, IL: American Marketing Association (2000).

8. Zeithaml, V.A., Parasuraman, A., and Berry, L. "Problems and strategies in services marketing", Journal of Marketing, 49(2), pp. 33-46 (1985).

9. Chopra, S. and Lariviere, M.A. "Managing service inventory to improve performance", MIT Sloan Management Review, 47(1), pp. 56-63 (2005).

10. Davis, M., Field, J., and Stavrulaki, E. "Using digital service inventories to create customer value", Service Science, 7(2), pp. 83-99 (2015).

11. Grönroos, C., Service Management and Marketing: Customer Management in Service Competition, John Wiley \& Sons (2007).

12. Battini, D., Persona, A., and Sgarbossa, F. "A sustainable EOQ model: theoretical formulation and applications", International Journal of Production Economics, 149(1), pp. 145-153 (2014).

13. Cárdenas-Barrón, L.E., Chung, K.J., and TreviñoGarza, G. "Celebrating a century of the economic order quantity model in honor of Ford Whitman Harris", International Journal of Production Economics, 155(1), pp. 1-7 (2014).

14. Taft, E.W. "The most economical production lot", Iron Age, 101(18), pp. 1410-1412 (1918).

15. Crowther, J.F. "Rationale for quantity discounts", Harvard Business Review, 42(2), pp. 121-127 (1964).

16. Diegel, A. "A linear approach to the dynamic inventory problem", Management Science, 12(7), pp. 530540 (1966).

17. Herron, D. "Inventory management for minimum cost", Management Science, 14(4), pp. B219-B235 (1967).

18. Wagner, H.M. and Whitin, T.M. "Dynamic version of the economic lot size model", Management Science, 5(1), pp. 89-96 (1958).

19. Aucamp, D.C. "A Solution to the multiple setup program", International Journal of Production Research, 22(4), pp. 549-554 (1984).

20. Chiu, H.N. and Chen, H.M. "The effect of timevalue of money on discrete time-varying demand lotsizing models with learning and forgetting considerations", The Engineering Economist, 42(3), pp. 203221 (1997).

21. Porteus, E., Foundations of Stochastic Inventory Theory, Stanford Business Books. California, USA (2002).
22. Tersine, R.J. and Price, R.L. "Temporary price discounts and EOQ", Journal of Purchasing and Materials Management, 17(4), pp. 23-27 (1981).

23. Khan, M., Jaber, M.Y., and Wahab, M.I.M. "Economic order quantity model for items with imperfect quality with learning in inspection", International Journal of Production Economics, 124(1), pp. 87-96 (2010).

24. Weiss, H.J. "Economic order quantity models with nonlinear holding costs", European Journal of Operational Research, 9(1), pp. 56-60 (1982).

25. Elsayed, E.A. and Teresi, C. "Analysis of Inventory Systems with Deteriorating Items", The International Journal of Production Research, 21(4), pp. 449-460 (1983).

26. Mahmoodi, A., Haji, A., and Haji, R. "A two-echelon inventory model with perishable items and lost sales", Scientia Iranica, 23(5), pp. 2277-2286 (2016).

27. Singh, S. and Rathore, H. "A two warehouse inventory model with preservation technology investment and partial backlogging", Scientia Iranica, 23(4), pp. 1952-1958 (2016).

28. Wu, C. and Zhao, Q. "An inventory model for deteriorating items with inventory-dependent and linear trend demand under trade credit", Scientia Iranica, 22(6), pp. 2558-2570 (2015).

29. Chung, K.J. "A theorem on the determination of economic order quantity under conditions of permissible delay in payments", Computers \& Operations Research, 25(1), pp. 49-52 (1998).

30. Salameh, M.K. and Jaber, M.Y. "Economic production quantity model for items with imperfect quality", International Journal of Production Economics, 64(1), pp. 59-64 (2000).

31. Cheng, Y., Wang, W., Wei, C., and Lee, K. "An integrated lot-sizing model for imperfect production with multiple disposals of defective items", Scientia Iranica, 25(2), pp. 852-867 (2018).

32. Dobos, I. and Richter, K. "A production/recycling model with stationary demand and return rates", Central European Journal of Operations Research, 8(2), pp. 173-194 (2003).

33. Dobos, I. and Richter, K. "An extended production/recycling model with stationary demand and return rates", International Journal of Production Economics, 90(3), pp. 311-323 (2004).

34. Dobos, I. and Richter, K. "A production/recycling model with quality consideration", International Journal of Production Economics, 104(2), pp. 571579 (2006).

35. Alinovi, A., Bottani, E., and Montanari, R. "Reverse logistics: a stochastic EOQ-based inventory control model for mixed manufacturing/remanufacturing systems with return policies", International Journal of Production Research, 50(5), pp. 1243-1264 (2012). 
36. Zhou, W. and Chen, L. "Research on the inventory control of the remanufacturing reverse logistics based on the quantitative examination", Scientia Iranica, 24(2), pp. 741-750 (2017).

37. Pentico, D.W. and Drake, M.J. "A survey of deterministic models for the EOQ and EPQ with partial backordering", European Journal of Operational Research, 214(2), pp. 179-198 (2011).

38. Mokhtari, H., Naimi-Sadigh, A., and Salmasnia, A. "A computational approach to economic production quantity model for perishable products with backordering shortage and stock-dependent demand", Scientia Iranica, 24(4), pp. 2138-2151 (2017).

39. Khan, M., Jaber, M.Y., Guiffrida, A.L., and Zolfaghari, S. "A review of extensions of a modified EOQ model for imperfect quality items", International Journal of Production Economics, 132(1), pp. 1-12 (2011).

40. Bouchery, Y., Ghaffari, A., Jemai, Z., and Dallery, Y. "Including sustainability criteria into inventory models", European Journal of Operational Research, 222(2), pp. 229-240 (2012).

41. Andriolo, A., Battini, D., Grubbström, R.W., Persona, A., and Sgarbossa, F. "A century of evolution from Harris's basic lot size model: Survey and research agenda", International Journal of Production Economics, 155, pp. 16-38 (2014).

42. Glock, C.H., Grosse, E.H., and Ries, J.M. "The lot sizing problem: A tertiary study", International Journal of Production Economics, 155, pp. 39-51 (2014).

43. Janssen, L., Claus, T., and Sauer, J. "Literature review of deteriorating inventory models by key topics from 2012 to 2015", International Journal of Production Economics, 182, pp. 86-112 (2016).

44. Bakker, M., Riezebos, J., and Teunter, R.H. "Review of inventory systems with deterioration since 2001", European Journal of Operational Research, 221(2), pp. 275-284 (2012).

45. Shekarian, E., Kazemi, N., Abdul-Rashid, S.H., and Olugu, E.U. "Fuzzy inventory models: A comprehensive review", Applied Soft Computing, 55, pp. 588621 (2017).

46. Kok, T. Grob, C., Laumanns, M., Minner S., Rambau, J., and Schade, K. "A typology and literature review on stochastic multi-echelon inventory models", European Journal of Operational Research, 269(3), pp. 955-983 (2018).

47. Thiel, D., Hovelaque, V., and Thi Le Hoa, V. "Impact of inventory inaccuracy on service-level quality in (Q,R) continuous-review lost-sales inventory models", International Journal of Production Economics, 123(2), pp. 301-311 (2010).

48. Samadi, F., Mirzazadeh, A., and Pedram, M.M. "Fuzzy pricing, marketing and service planning in a fuzzy inventory model: A geometric programming approach", Applied Mathematical Modelling, 37(1011), pp. 6683-6694 (2013).
49. Swenseth, S.R. and Olson, D.L. "Simulation model of professional service personnel inventory", International Journal of Services and Operations Management, 19(4), pp. 451-467 (2014).

50. Gzara, F., Nematollahi, E., and Dasci, A. "Linear location-inventory models for service parts logistics network design", Computers and Industrial Engineering, 69(1), pp. 53-63 (2014).

51. Byun, S.S., Balasingham, I., and Lee, H.N. "An inventory model-based spectrum pooling for wireless service provider and unlicensed users", Computer Communications, 36(10-11), pp. 1186-1192 (2013).

52. Schneider, H. "Effect of service-levels on order-points or order-levels in inventory models", International Journal of Production Research, 19(6), pp. 615-631 (1981).

53. Chen, F.Y. and Krass, D. "Inventory models with minimal service level constraints", European Journal of Operational Research, 134(1), pp. 120-140 (2001).

54. Vargo, S.L. and Lusch, R.F. "The four service marketing myths remnants of a goods-based, manufacturing model", Journal of Service Research, 6(4), pp. 324335 (2004).

55. Edvardsson, B., Gustafsson, A., and Roos, I. "Service portraits in service research - a critical review", International Journal of Service Industry Management, 16(1), pp. 107-121 (2005).

56. Gummesson, E. "Evert Gummesson: Stockholm University" in Services Marketing Self-Portraits: Introspections, Reflections, and Glimpses from the Experts, Raymond P. Fisk, Stephen F. Grove, and Joby John. Chicago: American Marketing Association, pp. 109132 (2000).

57. Vargo, S.L. and Lusch, R.F. "Service-dominant logic 2025", International Journal of Research in Marketing, 34(1), pp. 46-67 (2017).

58. Victorino, L., Field, J.M., Buell, R., Dixon, M.J., Meyer-Goldstein, S., Menor, L., Pullman, M.E., Roth, A.V., Secchi, E., and Zhang, J.J. "Service operations: What have we learned?", Journal of Service Management, 29(1), pp. 39-54 (2018).

59. Johnston, R. and Clark, G., Service Operations Management: Improving Service Delivery, Pearson Education (2008).

60. LaGanga, L.R. "Lean service operations: reflections and new directions for capacity expansion in outpatient clinics", Journal of Operations Management, 29(5), pp. 422-433 (2011).

61. Trienekens, J.J., Bouman, J.J., and Van Der Zwan, M. "Specification of service level agreements: Problems, principles and practices", Software Quality Journal, 12(1), pp. 43-57 (2004).

62. Mubeen, S., Asadollah, S.A., Papadopoulos, A.V., Ashjaei, M., Pei-Breivold, H., and Behnam, M. "Management of service level agreements for cloud services in IoT: A systematic mapping stud", IEEE Access, 6(1), pp. 30184-30207 (2018). 
63. Fitzsimmons, J. and Fitzsimmons, M., Service Management, 2d Ed., McGraw-Hill/Irwin, New York, USA (2004).

64. Kimes, S. "A strategic approach to yield management", in Ingold, A, McMahon-Beattie, U. and Yeoman, I. (eds.), Yield Management: Strategies for the Service Industries, London: Cengage Learning (2000).

65. Altin, M., Schwartz, Z., and Uysal, M. "Where you do it" matters: The impact of hotels' revenuemanagement implementation strategies on performance", International Journal of Hospitality Management, 67(1), pp. 46-52 (2017).

66. Kimes, S.E. "Perceived fairness of yield management", Cornell Hospitality Quarterly, 43(1), pp. 2130 (2002).

67. McMahon-Beattie, U. "Trust, fairness and justice in revenue management: Creating value for the consumer", Journal of Revenue \& Pricing Management, 10(1), pp. 44-46 (2011).

68. Taylor, W. and Kimes, S.E. "The effect of brand class on perceived fairness of revenue management", Journal of Revenue \& Pricing Management, 10(3), pp. 271-284 (2011).

69. Han, J., Kamber, M., and Pei, J., Data Mining: Concepts and Techniques, Third edition, Elsevier (2011).

70. Gummesson, E., Lusch, R., and Vargo, S. "Transitioning from service management to service-dominant logic: Observations and recommendations", International Journal of Quality and Service Sciences, 2(1), pp. 8-22 (2010).

71. Mehrez, A. and Ben-Arieh, D. "All-unit discounts, multi-item inventory model with stochastic demand, service level constraints and finite horizon", International Journal of Production Research, 29(8), pp. 1615-1628 (1991).

72. Lagodimos, A.G. "Multi-echelon service models for inventory systems under different rationing policies", International Journal of Production Research, 30(4), pp. 939-956 (1992).

73. Ouyang, L.-Y. and Wu, K.-S. "Mixture inventory model involving variable lead time with a service level constraint", Computers and Operations Research, 24(9), pp. 875-882 (1997).

74. Hillier, M.S. "Component commonality in a multipleperiod inventory model with service level constraints", International Journal of Production Research, 37(12), pp. 2665-2683 (1999).

75. Ouyang, L.-Y. and Chuang, B.-R. "Stochastic inventory models involving variable lead time with a service level constraint", Yugoslav Journal of Operations Research, 10(1), pp. 81-98 (2000).

76. Ouyang, L.-Y. and Chuang, B.-R. "A periodic review inventory model involving variable lead time with a service level constraint", International Journal of Systems Science, 31(10), pp. 1209-1215 (2000).
77. Xu, K., Evers, P.T., and Fu, M.C. "Estimating customer service in a two-location continuous review inventory model with emergency transshipments", European Journal of Operational Research, 145(3), pp. 569-584 (2003).

78. Lee, W.-C., Wu, J.-W., and Hou, W.-B. "Inventory model with a service level constraint for variable lead time demand with the mixtures of distribution", Journal of Interdisciplinary Mathematics, 7(2), pp. 125-151 (2004).

79. Chu, P., Yang, K.-L., and Chen, P.S. "Improved inventory models with service level and lead time", Computers and Operations Research, 32(2), pp. 285296 (2005).

80. Lee, W.-C., Wu, J.-W., and Hsu, J.-W. "Computational algorithm for inventory model with a service level constraint, lead time demand with the mixture of distributions and controllable negative exponential backorder rate", Applied Mathematics and Computation, 175(2), pp. 1125-1138 (2006).

81. Liang, S.-K., Chu, P., and Yang, K.-L. "Improved periodic review inventory model involving lead-time with crashing components and service level", International Journal of Systems Science, 39(4), pp. 421-426 (2008).

82. Hung, C.-Y., Hung, K.-C., Tang, W.-H., Lin, R., and Wang, C.-K. "Periodic review stochastic inventory models with service level constraint", International Journal of Systems Science, 40(3), pp. 237-243 (2009).

83. Jha, J.K. and Shanker, K. "Two-echelon supply chain inventory model with controllable lead time and service level constraint", Computers and Industrial Engineering, 57(3), pp. 1096-1104 (2009).

84. Jha, J.K. and Shanker, K. "A single-vendor singlebuyer production-inventory model with controllable lead time and service level constraint for decaying items", International Journal of Production Research, 47(24), pp. 6875-6898 (2009).

85. Tajbakhsh, M.M. "On the distribution free continuous-review inventory model with a service level constraint", Computers and Industrial Engineering, 59(4), pp. 1022-1024 (2010).

86. Xu, M. and Sun, C. "A multi-location inventory model for service parts with lateral transshipment and waiting time constraints", in Proceedings of 2010 International Conference on Logistics Systems and Intelligent Management, ICLSIM 2010, 1(1), pp. 3034 (2010).

87. Jaggi, C.K. and Arneja, N. "Periodic inventory model with reduced setup cost under service level constraint", Electronic Journal of Applied Statistical Analysis, 4(2), pp. 111-123 (2011).

88. Joshi, M. and Soni, H. "(Q, R) inventory model with service level constraint and variable lead time in fuzzy-stochastic environment", International Journal of Industrial Engineering Computations, 2(4), pp. 901-912 (2011). 
89. Cheng, F., Ettl, M., Lu, Y., and Yao, D.D. "A production-inventory model for a push-pull manufacturing system with capacity and service level constraints", Production and Operations Management, 21(4), pp. 668-681 (2012).

90. Lin, H.-J. "Effective investment to reduce setup cost in a mixture inventory model involving controllable backorder rate and variable lead time with a service level constraint", Mathematical Problems in Engineering, Art. ID 689061, pp. 1-15 (2012).

91. Ma, W.-M. and Qiu, B.-B. "Distribution-free continuous review inventory model with controllable lead time and setup cost in the presence of a service level constraint", Mathematical Problems in Engineering, Art. ID 867847, pp. 1-16 (2012).

92. Shahpouri, S., Fattahi, P., Arkan, A., and Parsa, $\mathrm{K}$. "Integrated vendor-buyer cooperative inventory model with controllable lead time, ordering cost reduction, and service-level constraint", International Journal of Advanced Manufacturing Technology, 65(5-8), pp. 657-666 (2013).

93. Jha, J.K. and Shanker, K. "Single-vendor multibuyer integrated production-inventory model with controllable lead time and service level constraints", Applied Mathematical Modelling, 37(4), pp. 17531767 (2013).

94. Hidayat, Y.A., Suprayogi, Islam, S.N., and Liputra, D.T. "Two-echelon inventory model with controllable reorder point and lead time subject to service level constraint", Proceedings of 2013 International Conference on Technology, Informatics, Management, Engineering and Environment, TIME-E 2013, pp. 119-125 (2013).

95. Bieniek, M. "Service level in model of inventory location with stochastic demand", Archives of Transport, 31(3), pp. 7-21 (2014).

96. Jiang, D.L., Zhu, G.F., and Li, D. "Two-echelon inventory stochastic model of supply chain based on service level constraints", Advanced Materials Research, 971-973, pp. 2448-2451 (2014).

97. Cheng, L., Tsou, C.-S., and Yang, D.-Y. "Cost-service tradeoff analysis of reorder-point-lot-size inventory models", Journal of Manufacturing Systems, 37(1), pp. 217-226 (2015).

98. Sarkar, B., Chaudhuri, K., and Moon, I. "Manufacturing setup cost reduction and quality improvement for the distribution free continuous-review inventory model with a service level constraint", Journal of Manufacturing Systems, 34(C), pp. 74-82 (2015).

99. Moon, I. and Choi, S. "The distribution-free continuous review inventory system with a service level constraint", Computers \& Industrial Engineering, 27(1), pp. 209-212 (1994).

100. Yilmaz, O.F., Baskak, M., and Erbiyik, H. "To define service level in an integrated model for warehouse and inventory planning by utilizing heuristic solution: An example", IEOM 2015 - 5th International Conference on Industrial Engineering and Operations Management, Proceeding, pp. 1-8 (2015).

101. Annadurai, K. "Minimax distribution-free procedure for mixture inventory model with variable lead time and a service level constraint by reducing order cost", American Journal of Mathematical and Management Sciences, 35(1), pp. 1-14 (2016).

102. Jaggi, C.K., Ali, H., and Arneja, N. "A technical note on periodic inventory model with controllable lead time under service level constraint", Electronic Journal of Applied Statistical Analysis, 9(1), pp. 8394 (2016).

103. Kurdhi, N., Diwiryo, T.A., and Sutanto, N.A. "An integrated production-inventory model for the single vendor two-buyer problem with partial backorder, stochastic demand, and service level constraints", Journal of Physics: Conference Series, 693(1), pp. 1-11 (2016).

104. Kurdhi, N., Sutanto, N.A., Kristanti, N.A., Prasetyawati, M.V., and Lestari, S.M. "Continuous review inventory models under service level constraint with probabilistic fuzzy number during uncertain received quantity", International Journal of Services and Operations Management, 23(4), pp. 443-466 (2016).

105. Hemapriya, S. and Uthayakumar, R. "An inventory model with uncertain demand and lost sales reduction under service level constraint", International Journal of Systems Assurance Engineering and Management, 8, pp. 1399-1418 (2017).

106. Jauhari, W.A. and Saga, R.S. "A stochastic periodic review inventory model for vendor-buyer system with setup cost reduction and service-level constraint", Production and Manufacturing Research, 5(1), pp. 371-389 (2017).

\section{Biographies}

Leopoldo Eduardo Cárdenas-Barrón is currently a Professor at School of Engineering and Sciences at Tecnológico de Monterrey, Campus Monterrey, México. $\mathrm{He}$ is also a faculty member at the Department of Industrial and Systems Engineering at Tecnológico de Monterrey. He was the Associate Director of the Industrial and Systems Engineering programme from 1999 to 2005. Moreover, he was also the Associate Director of the Department of Industrial and Systems Engineering from 2005 to 2009. His research areas include primarily related to inventory planning and control, logistics, and supply chain. He has published papers and technical notes in several international journals. He has co-authored one book in the field of simulation in Spanish.

Javier Reynoso is a Professor of Service Management at EGADE Business School, Monterrey, Mexico. His main interest is to promote and develop research and 
academic activities in the service field in Mexico and Latin America. Javier is the co-author of the first textbook on Service Management written in Spanish, used in 20 countries. Listed in the Top 15 MBA Professors in Latin America, by Revista America Economia in 2012, he has received the ITESM's Teaching and Research Faculty Award for his contributions to the service sector on three occasions: 1999, 2005, and 2013. He received the Christian Grönroos Service Research Award 2013 in recognition of his career achievements and significant originality in service research. In 2016 , Javier Reynoso was awarded International Fellow of CTF -Service Research Center- at Karlstad University in Sweden for his significant career contributions in service research.

Bo Edvardsson is a Professor and Founder, CTFService Research Center and Vice Rector, Karlstad University, Sweden. In 2008, he received the RESER
Award "Commendation for lifetime achievement to scholarship" by The European Association for Service Research and, in 2004, The AMA Career Contributions to the Services Discipline Award. In 2013, Bo was appointed Distinguished Faculty Fellow of the Center for Excellence in Service, University of Maryland and Honorary Distinguished Professor of Service Management, EGADE Business School, Monterrey Tech, Mexico. His research includes new service development and innovation, customer experience, complaint management, service eco-systems, and transition from product to service in manufacturing.

Karla Cabrera is a PhD Student at EGADE Business School, Monterrey, Mexico. She has contributed to more than 10 academic publications in service research. Her main interests are service management, service ecosystems, and services at the base of the pyramid. 